\title{
UPAYA PENINGKATAN PRESTASI BELAJAR SISWA MELALUI METODE DEMONSTRASI PADA TARI SELAMPIT DELAPAN DI SMAN 1 KOTA JAMBI
}

\author{
YULMARNI \\ SMA Negeri 1 Kota Jambi Provinsi Jambi \\ Email : yulmarnieen11@gmail.com
}

\begin{abstract}
ABSTRAK
Penelitian ini bertujuan untuk meningkatkan prestasi belajar siswa menggunakan metode demonstrasi pada materi tari Selampit Delapan di kelas X IPS 1 SMA Negeri 1 Kota Jambi, Provinsi Jambi tahun pelajaran 2018/2019. Pendekatan penelitian ini berjenis penelitian tindakan kelas (PTK) yang dilaksanakan dalam dua siklus. Tiap Instrumen yang digunakan yaitu lembar observasi. Teknik analisis data menggunakan rumus daya serap individu dan klasikal. Hasil penelitian ini menunjukkan bahwa terjadi peningkatan prestasi belajar siswa yang menggunakan metode demonstrasi pada materi Tari Selampit Delapan di kelas X IPS 1 SMA Negeri 1 Kota Jambi. Terlihat bahwa prestasi belajar siswa pada siklus II memperoleh persentase tuntas sebanyak $86,11 \%$ atau lebih dari standar daya serap klasikal yaitu $80 \%$ sehingga tindakan PTK (metode demonstrasi) dihentikan pada siklus II. Dari hasil penelitian ini diperoleh saran agar guru menggunakan metode demonstrasi untuk meningkatkan hasil belajar siswa khususnya pada praktik tari atau mata pelajaran Seni Budaya.
\end{abstract}

Kata Kunci: prestasi belajar siswa, metode demonstrasi, tari selampit delapan

\section{PENDAHULUAN}

Entitas pendidikan sebagai suatu sarana yang sangat penting bagi kelangsungan hidup manusia disebabkan karena, pendidikan melalui pengajaran, pelatihan, atau penelitian. Pendidikan merupakan sektor utama yang menjadi proses dalam meningkatkan kualitas kecerdasan manusia yang dapat mempengaruhi kelangsungan hidup seorang individu dan kelompok di masa yang akan datang. Sehingga dapat diartikan bahwa, pendidikan membangun peradaban yang bermartabat dan menjadi proses pembudayaan kemampuan, nilai, dan sikap dalam kehidupan masyarakat (Dai Lubis, 2014).

Peran pendidikan yang terlihat sebagai usaha kebudayaan bermaksud memberi tuntunan dalam hidup, munumbuhkan jiwa dan raga manusia agar kelak dalam garis kodrat pribadinya dan pengaruh segala keadaan yang mengelilinginya, mendapat kemajuan dalam hidup lahir batin menuju ke arah adab kemanusiaan. Usaha pendidikan yang pada dasarnya ditujukan pada tiga hal utama, yakni membentuk manusia yang memiliki kemampuan dalam mengolah kehalusan budi, kecerdasan otak dan pikiran, serta kesehatan badan jiwa dan raganya (Sudarsana, 2016). Dalam dunia pendidikan pada dasarnya siswa membutuhkan beberapa hal penting bagi perkembangan individu. Perkembangan tersebut secara umum meliputi: kreativitas, emosi, intelektual, persepsi serta kemampuan untuk berinteraksi dengan baik ditengah masyarakat. Kesemuanya itu terkait erat dengan kecerdasan emosional. Terbentuknya integritas kepribadian siswa, antara lain dicirikan oleh kehalusan rasa, sikap apresiatif, kreatif dan produktif salah satunya diyakini sebagai hasil pembelajaran seni. Hal ini harus menjadi bahan pertimbangan yang matang bagi para perumus kebijakan pendidikan (Isten, dkk, 2017).

Pendidikan seni budaya berfungsi mengembangkan kepekaan rasa, kreativitas, dan cita rasa estetis siswa dalam berkesenian, mengembangkan etika, kesadaran sosial dan kesadaran kultural siswa dalam kehidupan bermasyarakat, serta rasa cinta terhadap kebudayaan Indonesia. Mata pelajaran Seni Budaya meliputi bidang Seni Rupa, Seni Musik, Seni Tari dan Seni Teater, masing-masing bidang seni tersebut memiliki substansi, ciri-ciri pembelajaran dan materinya sendiri (Mardotillah, dkk, 2017). Seni budaya memberikan sumbangan kepada siswa agar berani dan siap bangga akan budaya bangsa sendiri dan menyokong dalam menghadapi tantangan masa depan adalah mata pelajaran seni budaya. Hal ini dikarenakan kompetensi 
dalam mata pelajaran ini merupakan bagian dari pembekalan life skill kepada siswa (Ardipal, 2012).

Pendidikan Seni Budaya diberikan di sekolah karena keunikan yang terletak pada pemberian pengalaman estetik dalam bentuk kegiatan berekspresi dan berapresiasi melalui pendekatan "Belajar dengan seni, belajar melalui seni dan belajar tentang seni" (Sumindar, dkk, 2012). Senada dengan hal tersebut Wibowo (2019) memaparkan bahwa Pendidikan Seni Budaya diberikan di sekolah karena keunikan, kebermaknaan, dan kebermanfaatan terhadap kebutuhan perkembangan siswa, yang terletak pada pemberian pengalaman estetik dalam bentuk kegiatan berekspresi/berkreasi dan berapresiasi melalui pendekatan: "belajar dengan seni," "belajar melalui seni" dan "belajar tentang seni." Peran ini tidak dapat diberikan oleh mata pelajaran lain. Dalam pendidikan seni, aktivitas berseni budaya harus menampung kekhasan tersebut yang tertuang dalam pemberian pengalaman mengembangkan konsepsi, apresiasi, dan kreasi. Semua ini diperoleh melalui upaya eksplorasi elemen, prinsip, proses, dan teknik berkarya dalam konteks budaya masyarakat yang beragam. Lebih lanjut Fauzi menjelaskan bahwa mata pelajaran Seni Budaya bertujuan untuk menumbuhkembangkan kepekaan rasa estetik dan artistik, sikap kritis, apresiatif dan kreatif pada diri setiap siswa secara menyeluruh. Sikap ini hanya mungkin tumbuh jika dilakukan serangkaian proses aktivitas berkesenian pada siswa. Oleh karena itu, mata pelajaran Seni Budaya memiliki peranan dalam pembentukan pribadi siswa yang harmonis dan mengembangkan kecerdasan majemuk (Fauzi, 2015).

Seni tari sebagai salah satu bidang liputan dalan Seni Budaya juga memiliki arah kekhususannya sendiri. Salah satu materi seni tari yang dpelajari untuk tingkat sekolah adalah mempraktikkan karya tari. Praktik karya tari merupakan kemampuan menirukan gerak tari dengan teknik yang tepat hingga membentuk suatu penyajian tari. Tari Selampit Delapan merupakan materi praktik tari yang dipelajari untuk siswa kelas X di SMA se-Kota Jambi. Sama dengan pembelajaran yang lain pada umumnya, tentu terdapat kesulitan untuk mencapai standar lulusan yang ingin dicapai. Kesulitan tersebut ditimbulkan oleh berbagai masalah yang ada pada siswa kelas X IPS 1 SMA Negeri 1 Kota Jambi. Permasalahan tersebut antara lain dijabarkan sebagai berikut: (1) Sulitnya menanamkan nilai seni pada siswa; (2) Globalisasi berpengaruh pada sikap siswa ketika belajar; (3) Praktik tari yang diberikan guru, kebanyakan tidak mampu mengikuti; (4) Motivasi belajar rendah; dan (5) Suasana belajar yang kurang menarik perhatian siswa.

Dari pemasalahan yang ditemukan, maka peneliti mengadakan perbaikan pembelajaran praktik tari dengan melakukan PTK dan menerapkan metode pembelajaran yang sesuai. Menurut Sanjaya dalam Sudira, dkk (2013) bahwa metode pembelajaran dapat diartikan sebagai cara yang digunakan untuk mengimplementasikan rencana pembelajaran yang sudah disusun dalam bentuk kegiatan nyata dan praktis sehingga tujuan dapat tercapai secara maksimal. Salah satu metode pembelajaran yang dianggap sesuai atau dapat mencapai tujuan praktik tari secara maksimal yaitu metode demonstrasi. Metode demonstrasi adalah suatu metode pembelajaran yang menunjukkan bahwa guru memperlihatkan suatu proses atau gerakgerik dan siswa menirukan atau mencontohnya untuk mencapai tujuan atau hasil yang optimal. Dari pengertian tersebut, metode demonstrasi dilakukan dengan memberikan contoh atau menunjukkan proses nyata sebuah materi contohnya tarian, maka tarian bukan diajarkan secara teori tetapi secara praktik menggerakkan tubuh sesuai jenis tarian yang dipelajari. Dengan demikian, metode demonstrasi dianggap sangat efektif dalam mencapai tujuan pembelajaran berpraktik seperti Tari Selampit Delapan.

Tari Selampit Delapan ini menggambarkan tentang sikap ramah tamah, sikap sosial antar teman, dan juga memiliki nilai kerjasama. Berdasarkan makna yang terdapat di Tari Selampit Delapan dapat diterapkan ke siswa (Rizky, dkk, 2015). Maka dari itu, siswa diharapkan memiliki sikap ramah tamah pada sesama teman, sikap saling menghargai dengan yang lebih tua termasuk guru, kemudian saling kerjasama dan memiliki sikap sosial, baik di lingkungan sekolah, maupun di lingkungan luar sekolah. Sikap dalam bersosial tersebut harus 
didasarkan dengan keahlian atau keterampilan manusia itu sendiri, sebagai acuan dalam bermasyarakat maupun di sekolah. Tari Selampit Delapan memiliki nilai sosial dalam berinteraksi sosial dan bekerjasama. Tarian ini dilakukan oleh delapan orang penari (empat pasang penari) yang masing-masing memegang satu helai selendang. Muda-mudi tersebut kemudian melakukan gerakan menyilang dan merajut selampit yang mereka genggam. Kemudian selampit itu menjadi satu tali yang tersusun menjadi berbagai warna. Nilai tarian inilah yang melambangkan persatuan antara muda-mudi di daerah Jambi. Tarian ini pada saat sekarang masih dipertunjukkan baik dalam acara formal dan non formal, seperti upacara penyambutan, pernikahan, perpisahan di sekolah, dan event-event lainnya. Tarian ini masih tetap terjaga keasliannya dan tidak mengalami perubahan, baik dari segi gerak ataupun komposisi tarian (Zari, 2019).

Berdasarkan uraian tersebut maka peneliti melakukan perbaikan melalui penelitian tindakan kelas yang berjudul: Upaya Peningkatan Prestasi Belajar Siswa Melalui Metode Demonstrasi Pada Tari Selampit Delapan di SMAN 1 Kota Jambi

\section{METODE PENELITIAN}

Metode penelitian yang digunakan adalah penelitian tindakan kelas (PTK). (Maisarah, 2019) mengartikan PTK sebagai metode penelitian yang mengkaji dan berupaya menyelesaikan masalah di dalam kelas dengan memberikan suatu tindakan baru. Pelaksanaan PTK sesuai prosedur yang dikemukakan oleh (Arikunto, 2012) bahwa pelaksanaan PTK terdiri dari beberapa siklus dan setiap siklus mempunyai empat tahapan yaitu: perencanaan, tindakan/observasi, refleksi, dan perbaikan. Penelitian Tindakan Kelas ini berlangsung pada bulan September-Oktober 2018 pada tahun pelajaran 2018/2019. Penelitian ini dilakukan di Kelas X IPS 1 SMA Negeri 1 Kota Jambi, Provinsi Jambi.

Teknik pengumpulan data yang digunakan adalah lembar observasi. Lembar observasi digunakan untuk mengukur hasil belajar siswa dalam mempraktekkan tari Selampit Delapan. Data yang diperoleh dari lembar observasi kemudian dianalisis dan dilakukan refleksi/ evaluasi untuk menentukan perbaikan atau ketuntasannya. Teknik analisis data tersebut menggunakan rumus persentase daya serap individu dan klasikal.

\section{HASIL DAN PEMBAHASAN Siklus I}

Tahap perencanaan, dilakukan dengan melakukan beberapa, yaitu: membuat RPP yang menggunakan metode demonstrasi, mempersiapkan media dan sumber belajar yang sesuai, serta sarana dan prasarana pendukung.

Tahap Pelaksanaan, guru melaksanakan tindakan sesuai dengan perencanaan yang telah dirumuskan. Melakukan pengamatan terhadap tindakan pembelajaran secara sistematis, objektif dan kritis. Pelaksanaan tindakan diuraikan sebagai berikut: (a) kegiatan awal meliputi membekali siswa dengan pembahasan tari Selampit Delapan, apersepsi, dan informasi kegiatan; (b) kegiatan inti meliputi pengamatan terhadap praktik tari yang didemonstrasikan, bertanya, menjawab atau menanggapi, menyimpulkan, dan mempraktikkan tarian yang telah didemonstrasikan; (c) kegiatan akhir meliputi pemberian umpan balik, pengayaan, dan latihan.

Tahap Observasi, Pada tahapan ini dilakukan pemantauan untuk mengetahui keberhasilan tindakan berupa metode demonstrasi terhadap peningkatan hasil prestasi belajar siswa. Untuk itu diperlukan instrumen observasi dan evaluasi tepat agar diperoleh data yang akurat. Data hasil observasi selanjutnya dijabarkan dan dianalisis pada tahap refleksi.

Tahap Refleksi, Pada tahap refleksi dilakukan penentuan sejauh mana hasil belajar siswa meningkat. Kegiatan ini dilakukan secara mandiri dan menjadi tanggung jawab peneliti. Hasil yang didapat dari tahap tindakan dan observasi dikumpulkan dan dianalisa pada tahap ini, sehingga didapat kesimpulan dari tindakan pada siklus I. Berikut hasil dari penelitian tindakan kelas pada siklus I: 
Tabel 1. Hasil Prestasi Belajar Pada Siklus I

\begin{tabular}{lll}
\hline Nilai KKM & $\begin{array}{l}\text { Jumlah } \\
\text { Siswa }\end{array}$ & Persentase \\
\hline$>67$ (tuntas) & 18 & $50 \%$ \\
$<67$ (tidak tuntas) 18 & $50 \%$ \\
\hline
\end{tabular}

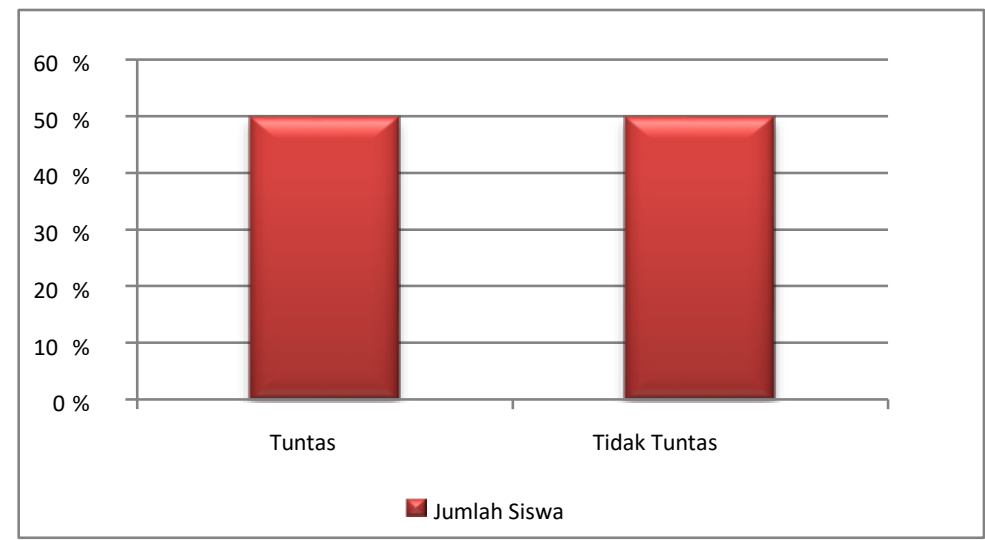

Gambar 1. Hasil Prestasi Belajar Pada Siklus I

Pada pelaksanaan siklus I, hasil prestasi belajar siswa pada materi praktik tari Selampit Delapan memang belum berhasil jika dilihat secara statistik. Namun, ketika pengamatan pada siklus I sudah banyak yang meningkat. Peningkatan yang terjadi pada siklus I adalah: (a) siswa sudah mulai memahami tentang tari Selampit Delapan dan memahami gerakan-gerakannya; (b) siswa juga lebih termotivasi saat pembelajaran dalam penelitian tindakan kelas ini berlangsung dibandingkan pembelajaran yang sebelumnya; (c) Guru Seni Budaya menurut pengamat juga sudah menunjukkan perbedaan cara mengajar dengan menggunakan metode demonstrasi; (d) sebagian siswa sudah mulai mampu mempraktikkan tari Selampit Delapan.

Penjelasan di atas, terlihat pada siklus I terdapat keberhasilan. Namun, ada juga kegagalan yang terjadi pada siklus I dimana kegagalan ini menjadi penyebab tidak berhasilnya ketuntasan mencapai 50\%, berikut kegalalan yang terjadi: (a) ketika guru memberikan pertanyaan, siswa terlihat bingung karena siswa tidak mampu menganalisis apa yang guru katakan; (b) kemudian siswa juga banyak yang bermain-main ketika guru mendemonstrasikan praktik tari Selampit Delapan; (c) hal yang paling utama yaitu pengalaman siswa yang sangat minim tentang tari Selampit Delapan, sehingga guru sangat kesulitan untuk mengharapkan siswa agar lebih aktif dalam belajar.

\section{Siklus II}

Hasil pada siklus I belum mencapai standar daya serap klasikal yaitu tuntas sebanyak $80 \%$. Oleh karena itu, tindakan menggunakan metode demonstrasi pada praktik tari Selampit Delapan dilanjutkan pada siklus II. Tahapan siklus II sama seperti siklus I namun terdapat beberapa perbedaan pada kegiatan setiap tahapan yang dijabarkan.

Tahap Perencanaan, Dari hasil analisa dan refleksi siklus I maka disusun kembali rencana tindakan II sebagai upaya mengatasi permasalahan yang belum terselesaikan. Kegiatan yang dilakukan pada tahapan ini masih tetap memuat perencanaan tindakan sebagai upaya mengatasi kesulitan siswa dalam mempraktikkan tari Selampit Delapan, yaitu dengan cara: membuat RPP yang menggunakan metode demonstrasi, mempersiapkan media dan sumber belajar yang sesuai, serta sarana dan prasarana pendukung.

Tahap Pelaksanaan, Pada tahap ini, guru melaksanakan tindakan sesuai dengan perencanaan yang telah dirumuskan. Melakukan pengamatan terhadap tindakan pembelajaran secara sistematis, objektif dan kritis. Pelaksanaan tindakan diuraikan sebagai berikut: (a) kegiatan awal meliputi membekali siswa dengan pembahasan tari Selampit Delapan, apersepsi, 
dan informasi kegiatan; (b) kegiatan inti meliputi pengamatan terhadap praktik tari yang didemonstrasikan, bertanya, menjawab atau menanggapi, menyimpulkan, dan mempraktikkan tarian yang telah didemonstrasikan; (c) kegiatan akhir meliputi pemberian umpan balik, pengayaan, dan latihan.

Tahap Observasi, Pada tahapan ini dilakukan pemantauan untuk mengetahui keberhasilan tindakan berupa metode demonstrasi terhadap peningkatan hasil prestasi belajar siswa. Untuk itu diperlukan instrumen observasi dan evaluasi tepat agar diperoleh data yang akurat. Data hasil observasi selanjutnya dijabarkan dan dianalisis pada tahap refleksi.

Pada tahap refleksi dilakukan penentuan sejauh mana hasil prestasi belajar siswa meningkat. Kegiatan ini dilakukan secara mandiri dan menjadi tanggung jawab peneliti. Hasil yang didapat dari tahap tindakan dan observasi dikumpulkan dan dianalisa pada tahap ini, sehingga didapat kesimpulan dari tindakan pada siklus II. Berikut hasil dari penelitian tindakan kelas pada siklus II:

Tabel 2. Hasil Prestasi Belajar Pada Siklus II

\begin{tabular}{lll}
\hline Nilai KKM & Jumlah Siswa & Persentase \\
\hline$>67$ (tuntas) & 31 & $86,11 \%$ \\
$<67$ (tidak tuntas) & 5 & $13,89 \%$ \\
\hline
\end{tabular}

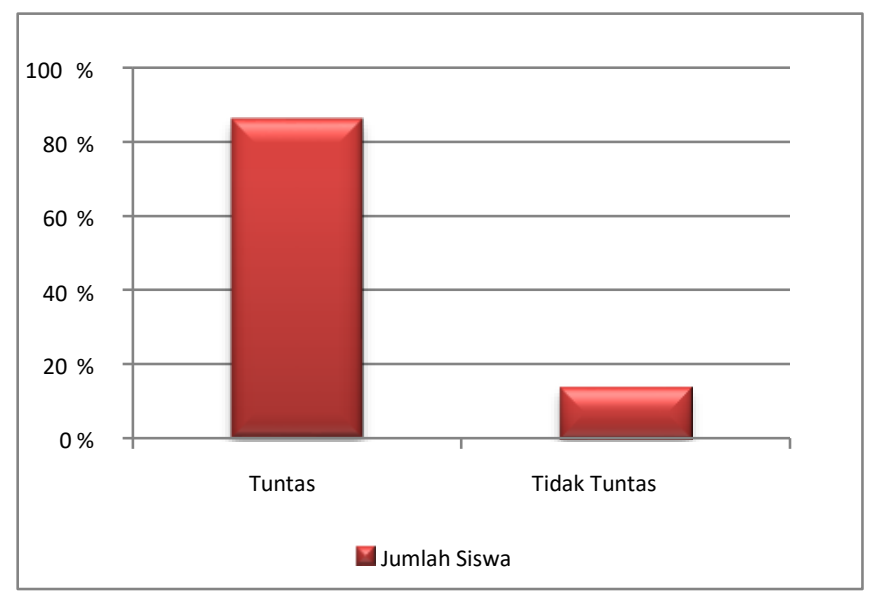

\section{Gambar 2. Hasil Prestasi Belajar Pada Siklus II}

Pada pelaksanaan siklus II, hasil prestasi belajar siswa pada materi praktik tari Selampit Delapan meningkat secara signifikan dari $50 \%$ siswa tuntas pada siklus I menjadi $86,11 \%$ tuntas pada siklus II. Namun, ketika pengamatan pada siklus II masih terdapat beberapa kekurangan, yaitu: (a) masih ada siswa yang belum memahami secara baik tentang penjiwaan tari Selampit Delapan; dan (b) masih ada siswa yang kesulitan mempraktikkan tari Selampit Delapan. Namun beberapa kekurangan tersebut hanya terjadi pada siswa yang hasil belajarnya belum tuntas sedangkan siswa yang tuntas sebanyak $86,11 \%$ tidak mengalami kekurangan tersebut. Jika metode demonstrasi secara berkelanjutan dan dilakukan perbaikan maka besar kemungkinan kekurangan tersebut tidak terjadi.

\section{Pembahasan}

Pada pelaksanaan siklus I, hasil prestasi belajar siswa pada materi praktik tari Selampit Delapan memang belum berhasil jika dilihat secara statistik. Namun, ketika pengamatan pada siklus I sudah banyak yang meningkat, mulai dari pemahaman tentang defenisi, makna dan asal usul dari tari Selampit Delapan. Siswa yang tuntas pada siklus I berjumlah 18 orang dengan presentase $50 \%$ dan siswa yang belum mencapai ketuntasan berjumlah 18 orang dengan presentase $50 \%$. Sedangkan pada siklus II, peningkatan hasil prestasi belajar secara statistik 
terlihat dengan jelas. Siswa yang tuntas pada siklus II berjumlah 31 orang dengan presentase $86,11 \%$ dan siswa yang belum mencapai ketuntasan berjumlah 5 orang dengan presentase $13,89 \%$. Berdasarkan hasil penelitian siklus II yang mana terdapat $86,11 \%$ yang tuntas, maka diperoleh kesimpulan bahwa: terjadi peningkatan prestasi belajar siswa yang menggunakan Metode Demonstrasi pada materi tari Selampit Delapan di Kelas X IPS-I SMA Negeri 1 Kota Jambi.

Peningkatan prestasi belajar siswa terjadi akibat dari tindakan metode demonstrasi yang diterapkan sebanyak dua siklus. (Angkowo \& Kosasih, 2007) menuturkan bahwa hasil belajar siswa dipengaruhi oleh dua faktor utama yaitu faktor yang datang dari dalam diri siswa dan faktor yang datang dari luar diri siswa atau lingkungan. Faktor dari dalam diri siswa menyangkut kemampuan yang dimilik siswa sebesar 70\% dan faktor lingkungan sebesar 30\%. Senada dengan pernyataan (Slameto, 2003) bahwa ada dua faktor yang mempengaruhi hasil belajar yaitu faktor dalam (internal) dan faktor luar (eksternal). Faktor internal adalah faktor yang datangnya dari dalam diri siswa itu sendiri, yang meliputi pengamatan, fantasi, perasaan, kecerdasan, bakat, minat dan perhatian. Pengamatan anak akan mempengaruhi hasil belajar, namun hasil pengamatan itu ditentukan juga oleh keadaan fisik anak tersebut. Fantasi adalah daya jiwa untuk menciptakan tanggapan-tanggapan atas kesan-kesan yang baru dan dengan bantuan tanggapan yang sudah ada. Perasaan merupakan daya yang sangat penting dalam diri siswa, perasaan mencerminkan kepribadian seseorang dengan dunia luar. Biasanya perasaan berwujud senang atau tidak senang, gembira atau sedih, simpati atau antipati, suka atau benci terhadap pelajaran yang diikutinya. Metode demonstrasi termasuk pada faktor eksternal yang dapat mempengaruhi hasil prestasi belajar siswa.

Metode demonstrasi adalah suatu metode pembelajaran yang menunjukkan bahwa guru memperlihatkan suatu proses atau gerak-gerik dan siswa menirukan atau mencontohnya untuk mencapai tujuan atau hasil yang optimal. Dari pengertian tersebut, metode demonstrasi dilakukan dengan memberikan contoh atau menunjukkan proses nyata sebuah materi contohnya tarian, maka tarian bukan diajarkan secara teori tetapi secara praktik menggerakkan tubuh sesuai jenis tarian yang dipelajari. Dengan demikian, metode demonstrasi dianggap sangat efektif dalam mencapai tujuan pembelajaran berpraktik seperti tari Lenggang Patah Sembilan. Hal ini didukung oleh beberapa hasil penelitian terdahulu yang relevan dan telah diterbitkan pada jurnal nasional maupun internasional sebagai berikut:

Penelitian (Nawir, dkk, 2015) menyarankan agar dalam kegiatan belajar mengajar di kelas, guru diharapkan untuk menerapkan metode pembelajaran demonstrasi sebagai suatu metode dalam mata pelajaran Pendidikan Seni Budaya. (Saputra, 2015) dalam penelitiannya menyimpulkan bahwa penggunaan metode pembelajaran demonstrasi berpengaruh positif terhadap peningkatan hasil belajar siswa kelas XI SMA 15 Padang pada mata pelajaran seni budaya. Penelitian ini diharapkan dapat dijadikan sebagai referensi untuk bahan inovasi dalam meningkatkan mutu pendidikan di sekolah dan memfariasikan berbagai metode pembelajaran yang menyenangkan bagi peserta didik agar proses pembelajaran menjadi efektif dan efesien. Sehingga dapat memberikan dorongan motivasi antar siswa agar bisa menyelesaikan tugas yang harus dicapai bersama-sama. Hasil penelitian (Rodiyah, 2015) menunjukkan bahwa penerapan metode demonstrasi didukung metode ceramah dan berbantuan media LCD, diperoleh hasil proses pembelajaran elemen gerak tari siswa kelas VII A SMP dalam mata pelajaran seni budaya (elemen gerak tari) dapat dilihat dari segi kognitif, afektif, dan psikomotor. Segi kognitif yaitu siswa dapat mendeskripsikan ragam elemen gerak tari, segi afektif yaitu dapat dilihat dari siswa yang bisa melakukan elemen gerak tari dengan ekspresi wajah, dan segi psikomotor dapat dilihat dalam proses pembelajaran siswa yang mampu melakukan elemen gerak tari dari awal hingga akhir dengan tehnik gerak yang benar. Cara ini dapat meningkatkan aktivitas siswa dalam hal pemahaman materi dan kerja sama dengan teman, berani mengeluarkan pendapat dan bertanya, sehingga memberikan situasi belajar yang menyenangkan bagi siswa untuk giat belajar, juga meningkatkan kemampuan dan hasil belajarnya. 
Penelitian (Septianingsih, 2018) membuktikan bahwa hasil belajar tari Bedana menggunakan metode demonstrasi pada kegiatan ekstrakurikuler di SMA Negeri 1 Seputih Raman secara keseluruhan mendapatkan kriteria baik dengan peningkatan kemampuan gerak siswi pada setiap pertemuan, dan secara keseluruhan mendapatkan nilai 78,87. Dari hasil penelitian (Hasibuan et al., 2019) disimpulkan bahwa aktivitas belajar siswa pada pembelajaran dengan menggunakan metode latihan (Drill) mengalami penigkatan setiap siklusnya. Nilai ratarata siswa pada saat pre test sebelum diberikan tindakan sebesar 73,4 dan dinyatakan masih belum tuntas, pada siklus I nilai rata-rata siswa meningkat sebesar 77,6 dengan tingkat ketuntasan belajar $66,7 \% \%$ yang memiliki hasil nilai cukup baik, dan pada siklus II nilai ratarata siswa meningkat menjadi 82,5 dengan tingkat ketuntasan belajar 97,2\% yang memiliki hasil nilai yang baik. Jadi dapat disimpulkan secara umum bahwa melalui penguatan hasil belajar dapat meningkat dengan menggunakan metode demonstrasi dan latihan. Penelitian (Deswarni \& Budiwirman, 2019) membuktikan bahwa ada pengaruh tindakan (metode demonstrasi) yang diberikan terhadap peningkatan kemampuan siswa dalam membaca notasi musik dari siklus I ke siklus ke II meningkat menjadi 16,18\%. Penelitian ini menyarankan perlu ada upaya-upaya terhadap peningkatan kemampuan guru-guru Seni Budaya dalam menyajikan pembelajaran secara interaktif, bermakna, menantang dan menyenangkan. Agar pembelajaran Seni Budaya dilaksanakan berdasarkan kepada rencana pelaksanaan pembelajaran yang telah dipersiapkan sebelumnya, sehingga permasalahan kekurangan waktu penyajian dapat diatasi.

Dari beberapa hasil penelitian di atas terbukti bahwa metode demonstrasi dapat mempengaruhi bahkan meningkatkan hasil belajar peserta didik pada mata pelajaran Seni Budaya, khususnya pada Seni Rupa, Seni Musik, dan Seni Tari.

\section{KESIMPULAN}

Berdasarkan hasil penelitian tersebut, maka dapat disimpulkan bahwa pada pelaksanaan siklus I, hasil prestasi belajar siswa pada materi praktik tari Selampit Depalan memang belum berhasil jika dilihat secara statistik. Namun, ketika pengamatan pada siklus I sudah banyak yang meningkat, mulai dari pemahaman tentang defenisi, makna dan asal usul dari tari Selampit Depalan. Siswa yang tuntas pada siklus I berjumlah 18 orang dengan presentase $50 \%$ dan siswa yang belum mencapai ketuntasan berjumlah 18 orang dengan presentase $50 \%$. Sedangkan pada siklus II, peningkatan hasil prestasi belajar secara statistik terlihat dengan jelas. Siswa yang tuntas pada siklus II berjumlah 31 orang dengan presentase $86,11 \%$ dan siswa yang belum mencapai ketuntasan berjumlah 5 orang dengan presentase 13,89\%. Berdasarkan hasil penelitian siklus II yang mana terdapat $86,11 \%$ yang tuntas, maka diperoleh kesimpulan bahwa: terjadi peningkatan prestasi belajar siswa yang menggunakan Metode Demonstrasi pada materi tari Selampit Depalan di Kelas X IPS I SMA Negeri 1 Kota Jambi tahun pelajaran 2018/2019.

Dengan diadakannya penelitian tindakan kelas ini. Maka guru sebagai peneliti menyarankan bahwa: 1) Guru Seni Budaya harus mampu menyesuaikan metode pembelajaran dengan materi yang diajarkan; 2) Untuk mengajarkan praktik tari Selampit Depalan haruslah dilakukan pemahaman konsep metode oleh guru; dan 3) Metode demonstrasi sangat tepat untuk pembelajaran seni tari.

\section{DAFTAR PUSTAKA}

Angkowo, R., \& Kosasih, A. (2007). Optimalisasi Media Pembelajaran. Jakarta: Grasindo.

Ardipal, A. (2012). Kurikulum Pendidikan Seni Budaya yang Ideal bagi Peserta Didik di Masa Depan. Komposisi: Jurnal Pendidikan Bahasa, Sastra, dan Seni, 11(1).

Arikunto, S. (2012). Penelitian Tindakan Kelas. Jakarta: Bumi Aksara.

Dai Lubis, M. (2014). Upaya Meningkatkan Hasil Belajar Menggambar Pemandangan Menggunakan Cat Air Dengan Strategi Kooperatif Tipe Jigsaw Pada Siswa Kelas Xi Sma Negeri 4 Kisaran Tp 2013/2014 (Doctoral dissertation, UNIMED).

Fauzi, H. D. (2015). Buku Guru Seni Budaya. Bandung: Yrama Widiya. 
Maisarah. (2019). Metodologi Penelitian Pendidikan Pendekatan Kuantitatif. Medan: Akasha Sakti.

Mardotillah, M., \& Zein, D. M. (2017). Silat: Identitas budaya, pendidikan, seni bela diri, pemeliharaan kesehatan. Jurnal Antropologi: Isu-Isu Sosial Budaya, 18(2), 121-133.

Nawir, Arafah, K., \& Pristiwaluyo, T. (2015). Penerapan Metode Demonstrasi Untuk Meningkatkan Keterampilan Melukis Peserta Didik Kelas XII IPA 3 SMA Negeri 1 Donri Donri Kabupaten Soppeng. Penelitian Dan Evaluasi Pendidikan, 1(1), 1-8.

Isten, C., Rohiat, R., \& Djuwita, P. (2017). Pengelolaan Pembelajaran Seni Budaya di SMA. Manajer Pendidikan, 11(6).

Rizky, R., \& Wibisono, T. (2015). Mengenal Seni \& Budaya 34 Provinsi di Indonesia. CERDAS INTERAKTIF.

Rodiyah, S. (2015). Metode Demonstrasi Dalam Pembelajaran Elemen Gerak Tari Mata Pelajaran Seni Budaya Siswa Kelas VII A SMP Negeri 26 Semarang. Universitas Negeri Semarang.

Slameto. (2003). Belajar dan Faktor-Faktor yang Mempengaruhinya. Jakarta: Rineka Cipta.

Septianingsih, N. M. D. (2018). Penggunaan Metode Demonstrasi Pada Pembelajaran Tari Bedana Dalam Kegiatan Ekstrakurikuler Di SMA N 1 Seputih Raman Lampung Tengah. Universitas Lampung.

Sudarsana, I. K. (2016). Peningkatan mutu pendidikan luar sekolah dalam upayapembangunan sumber daya manusia. Jurnal Penjaminan Mutu, 1(1), 1-14.

Sudira, I. N., Suhandana, A., \& Marhaeni, A. A. I. N. (2013). Pengaruh Metode Pembelajaran Drill Terhadap Prestasi Belajar Seni Tari Ditinjau Dari Kreativitas Pada Siswa Kelas X Smk Negeri 3 Sukawati. Jurnal Administrasi Pendidikan Indonesia, 4(1).

Sumindar, A., \& Lestari, W. (2012). Model Pembelajaran Moving Class Mata Pelajaran Seni Budaya Dan Implikasinya Terhadap Kemandirian Siswa (Kajian Kasus) Di SMA Karangturi Semarang. Catharsis, 1(2).

Wibowo, J. I. (2019). Peningkatan Kemampuan Mengidentifikasi Keunikan Gagasan Dan Teknik Dalam Karya Seni Kriya Mancanegara Dengan Menggunakan Model Pembelajaran Langsung Siswa Kelas XI. IPA. 2 SMA Negeri 1 Dagangan Kabupaten Madiun. Wahana Kreatifitas Pendidik (WKP), 2(1), 44-48.

Zari, N. (2019). Pembelajaran Tari Selampit Delapan Tulang Belut Melalui Model Cooperative Learning Untuk Meningkatkan Karakter SosiaL (Doctoral dissertation, Universitas Pendidikan Indonesia). 